\title{
Common mechanisms underlying opioid tolerance and dependence, and neuropathic pain: Role of metabotropic glutamate receptors
}

Marian E Fundytus PhD

\begin{abstract}
ME Fundytus.
Common mechanisms underlying opioid tolerance/dependence and neuropathic pain: Role of metabotropic glutamate receptors.

Pain Res Manage 2000;5(1):40-48.

It has been suggested that opioid tolerance and dependence share common mechanisms with neuropathic pain. This short review deals with the role of glutamate and glutamate receptors in opioid tolerance and dependence, and neuropathic pain. Particular attention is given to the role of metabotropic glutamate receptors (mGluRs). First, the different types of glutamate receptors, which include $N$-methyl-D-aspartate, alpha-amino-3-hydroxyl-5-methylisoxazole-4-propionic acid, kainate and mGluRs, are described. Following this, evidence suggesting that these receptors are involved in opioid tolerance and dependence are summarized. At the end of this section, a model that has been previously proposed to explain mechanisms by which mGluRs may be involved in opioid tolerance and dependence are described. Next is a discussion of the evidence suggesting that glutamate receptors are similarly involved in neuropathic pain, and also in opioid sensitivity associated with neuropathic pain. Again, a hypothetical model used to explain mechanisms by which mGluRs may be involved in neuropathic pain is briefly described. The relevance of the data is discussed in terms of some of the clinical implications of the material presented in the article.
\end{abstract}

Key Words: Glutamate; Metabotropic glutamate; Metabotropic glutamate receptors; Neuropathy; N-methyl-D-aspartate; Opioid; Opioid dependence; Opioid tolerance; Pain

\section{Mécanismes communs sous-jacents à la tolérance et à la dépendance aux substances opioïdes, ainsi qu'aux douleurs névropathiques : rôle des récepteurs du glutamate métabotropique}

RÉSUMÉ : La tolérance et la dépendance aux substances opioïdes partageraient des mécanismes communs aux douleurs névropathiques. Il sera question, dans le présent survol, du rôle du glutamate et des récepteurs du glutamate dans la tolérance et la dépendance aux substances opioïdes, ainsi que dans les douleurs névropathiques. Une attention particulière est accordée au rôle des récepteurs du glutamate métabotropique (mGluR). Tout d'abord, on décrit les différents types de récepteur du glutamate, notamment le $N$-méthyl-D-aspartate, l'alpha-amino-3-hydroxyl-5-méthyl-isoxazole-4-acide proprionique, le kaïnate et les mGluR. Suit un résumé des données selon lesquelles ces récepteurs sont mis en cause dans la tolérance et la dépendance aux substances opioïdes. À la fin de cette partie, on décrit un modèle déjà proposé pour expliquer comment les mGluR pourraient participer à ce phénomène de tolérance et de dépendance. Ensuite, il y a une discussion sur les éléments qui donnent à penser que les récepteurs du glutamate sont également mis en cause dans les douleurs névropathiques ainsi que dans la sensibilité aux substances opioïdes, associée aux douleurs névropathiques. Encore une fois, on fait une brève description du modèle hypothétique utilisé pour expliquer comment les mGluR contribueraient aux douleurs névropathiques. La pertinence des données est ici discutée en fonction de certaines des incidences cliniques du matériel présenté dans l'article. 
$\mathrm{N}$ ormally, the perception of pain serves as a defense mechanism. When tissue injury occurs, pain causes an organism to initiate a withdrawal response or to avoid use of the injured body part to prevent further injury. However, extreme pain and chronic pain, especially pain that persists after healing is complete, may become counterproductive and debilitating. Thus, the treatment of pain is a major goal of medical care. The most commonly used analgesics are opioids such as morphine. However, the repeated use of opioids may lead to the development of tolerance and dependence. Tolerance is defined as a decreased efficacy of the drug, leading to the requirement for increased doses to achieve the desired analgesic effect. Dependence is a continued need for the drug to maintain a state of physiological equilibrium following repeated administration and leads to an aversive withdrawal syndrome upon removal of the drug. It has been postulated that opioid tolerance and dependence, and one type of chronic pain, neuropathic pain, may share common mechanisms (1). Neuropathic pain syndromes may arise from disease states that progress to nerve injury, such as diabetic neuropathy and postherpetic neuralgia. Neuropathic syndromes may be the result of a traumatic nerve injury, which may be inflicted from a gunshot wound or a car accident. Cancer patients often experience neuropathic pain as a result of either nerve compression by the tumour or cancer treatment-induced nerve damage (radiation damage and chemotherapeutic toxicity). Other neuropathic pain syndromes have a less well defined etiology, and include fibromyalgia and trigeminal neuralgia. Neuropathic pain syndromes are characterized by spontaneous pain, hyperalgesia (increased responsiveness to noxious stimuli) and allodynia (pain-like responsiveness to normally innocuous stimuli) (2-4). The most commonly reported symptoms in patients are cold hyperalgesia, mechanical allodynia and spontaneous pain. Neuropathic pain is particularly difficult to treat and is often unresponsive to opioids (5-7). In this article, the role of glutamate and its receptors, particularly metabotropic glutamate receptors (mGluRs), in opioid tolerance and dependence, and in neuropathic pain and opioid sensitivity associated with neuropathic pain are discussed. Proposed models to explain mechanisms by which mGluRs may be involved in opioid tolerance and dependence, and neuropathic pain are also summarized.

\section{GLUTAMATE RECEPTORS}

Glutamate receptors (GluRs) are divided into two broad categories of receptors: ionotropic (iGluRs; they are coupled to ion channels) and mGluRs (they are coupled to guanine nucleotide regulatory $[\mathrm{G}]$ proteins).

The most widely studied GluRs are those that are differentially sensitive to $N$-methyl-D-aspartate (NMDA) receptors. NMDA receptors are composed of four transmembrane domains similar to other ligand-gated channels, an extracellular $\mathrm{N}$-terminus and an intracellular C-terminus (8). NMDA receptors are coupled to an ion channel permeable to calcium, sodium and potassium $(9,10)$, and are gated in a voltage- dependent manner by magnesium $(11,12)$. The NMDA receptor has several binding sites. These include the ligand binding site where glutamate and NMDA act, the phencyclidine (PCP) site inside the ion channel at which noncompetitive antagonists such as MK-801 bind, polyamine binding sites, a distinct site for zinc binding and a redox binding site (13-18). NMDA receptors mediate slow, excitatory postsynaptic potentials, and activation of these receptors leads to the activation of protein kinase $\mathrm{C}(\mathrm{PKC})$ and the production of nitric oxide (19).

Receptors differentially sensitive to alpha-amino3-hydroxy-5-methylisoxazole-4-propionic acid (AMPA) and kainate are also known as iGluRs, and are coupled to ion channels permeable to sodium, potassium and in some configurations calcium (lacking the GluR2 subunit) (20-22). AMPA and kainate receptors mediate fast excitatory postsynaptic potentials (23-26).

Glutamate also acts at a family of receptors known as mGluRs, which are directly coupled to intracellular second messengers via $G$ proteins. The mGluRs are divided into three groups based on sequence homology, signal transduction mechanisms and receptor pharmacology $(27,28)$. Group I mGluRs, which include mGluR1 and mGluR5, are positively coupled to phosphatidylinositol (PI) hydrolysis. Activation of these receptors leads to phospholipase C (PLC) catalyzed hydrolysis of phosphoinositol-4,5-bisphosphate (PIP2) into diacylglycerol (DAG) and inositol-1,4,5trisphosphate (IP3). DAG promotes the translocation and activation of PKC. IP3 stimulates the release of calcium from stores in the endoplasmic reticulum. Calcium also promotes the translocation and activation of PKC. Group II mGluRs, which include mGluR2 and mGluR3, and group III mGluRs (mGluR4,6,7,8) are negatively coupled to the enzyme adenylate cyclase, and activation of these receptors inhibits the production of cyclic adenosine-3',5'-monophosphate. Activity at group I mGluRs positively modulates NMDA receptor activity via a PKC-mediated mechanism (29-34), while activity at group II and III mGluRs negatively modulates NMDA receptor activity (35).

\section{GLUTAMATE AND OPIOID TOLERANCE AND DEPENDENCE}

A role for glutamate in the development of opioid tolerance and dependence has been well established. Glutamate release is enhanced in the spinal cord and locus coeruleus of rats during opioid withdrawal $(36,37)$. Moreover, intracerebroventricular injection of glutamate in morphine-dependent rats has been shown to precipitate withdrawal symptoms (38), and inhibition of glutamate release with lamotrigine attenuated the precipitated withdrawal symptoms (39).

As early as the 1970s, Koyuncuoglu and colleagues (40) postulated that the excitatory amino acids glutamate and aspartate played a role in opioid tolerance and dependence. This group of investigators showed that aspartate antagonized morphine's effects, and reduced the development of morphine tolerance and dependence $(40,41)$. In later work, 
Koyuncuoglu and colleagues (42) showed that NMDA receptor antagonists such as ketamine and dextromethorphan attenuated the severity of morphine withdrawal symptoms in rats. The role of NMDA receptors in the development of opioid tolerance and dependence has been verified by many other investigators (43-62) who showed that antagonism of NMDA receptors (with competitive and noncompetitive antagonists) attenuates these phenomena. More recently, it has been shown that administration of antagonists to the glycine site of the NMDA receptor attenuates opioid withdrawal symptoms (63-65). Antisense oligonucleotide knockdown of NMDA receptors has also been shown to reduce precipitated withdrawal symptoms (66). However, it should be noted that some investigators (67-69) have observed that although NMDA antagonists block the development of tolerance to morphine, they fail to affect the development of tolerance to more selective mu-, delta- or kappa-opioid receptor agonists. Contrary to the usual observations, one group (70) even found that cotreatment of rats with the NMDA antagonist MK-801 and morphine exacerbated the precipitated withdrawal symptoms.

The role of AMPA and kainate receptors in opioid tolerance and dependence seems to be more complex and controversial. Some investigators $(71,72)$ have found that treatment with AMPA/kainate antagonists either systemically or directly into the locus coeruleus or central nucleus of the amygdala reduced withdrawal-induced locus coeruleus activation and behavioural symptoms. However, others have shown that while systemic administration of AMPA/kainate antagonists reduced the development of tolerance and acute dependence, there was no effect on the development of chronic dependence (73). Moreover, although systemic administration of a selective AMPA antagonist has been shown to attenuate the development of tolerance to morphine, it failed to affect the development of tolerance to selective delta- or kappa-opioid receptor agonists (74). In our laboratory, we have shown (59) that intracerebroventricular administration of an AMPA/kainate antagonist failed to reduce the precipitated withdrawal symptoms in morphine-dependent rats.

We have examined the role of mGluRs in opioid dependence and tolerance. We first showed (59) that chronic intracerebroventricular administration of either the nonselective mGluR antagonist L-2-amino-3-phosphonopropanoic acid (L-AP3), or the relatively selective group I mGluR antagonist (S)-4-carboxyphenylglycine ([S]-4CPG), concurrently with subcutaneous administration of morphine, significantly attenuated the severity of precipitated withdrawal symptoms. Very recent work from our laboratory showed that antisense oligonucleotide knockdown of spinal mGluR1 attenuated the development of tolerance to morphine (Sharif, et al, unpublished observations). Subsequently, we showed that chronic intracerebroventricular administration of either the nonselective mGluR antagonist alpha-methyl-4carboxyphenylglycine, the selective group II antagonist $2 \mathrm{~s}, 1^{\prime} \mathrm{s}, 2^{\prime} \mathrm{s}-$ 2-methyl-2-(2'-carboxycyclopropyl)-glycine, or the selective group III mGluR antagonist alpha-methyl-L-amino-4-phosphonobutanoate (MAP4), concurrently with subcuta- neous morphine significantly reduced the severity of the precipitated withdrawal symptoms (75). Similarly, it has been shown that antagonism of group II mGluRs attenuated morphine-induced activation of locus coeruleus neurons (76). In addition, we demonstrated that a single intracerebroventricular injection of the selective group II mGluR agonist 2S, 1'R,2'R3'R-2-(2',3'-dicarboxycyclopropyl)glycine, just before the precipitation of withdrawal, significantly reduced the severity of abstinence symptoms (77). Our results were verified by another group of investigators (76) who showed that pretreatment with the group II mGluR agonist LY34570 also significantly reduced the severity of abstinence symptoms in rats. Thus, we first established that mGluRs play a significant role in the development of opioid dependence, and this contention has been borne out by further research.

As discussed above, group I mGluRs are positively coupled to PI hydrolysis, and activation of these receptors ultimately leads to the activation of PKC and release of intracellular calcium. Thus, because antagonism of group I mGluRs with (S)-4CPG attenuated morphine withdrawal, it was interesting to examine the role of products of PI hydrolysis in opioid dependence. Toward this end, we showed that chronic inhibition of PKC as well as intracellular calcium release in the brain significantly reduced the severity of precipitated abstinence symptoms (78). Other investigators $(1,79-82)$ have also shown that inhibition of PKC, as well as other protein kinases, reduces tolerance and dependence associated with repeated opioid administration in rats. Moreover, it has been shown that tolerance is associated with increases in PKC immunoreactivity (83) and activated PKC (80).

Based on our results, and those of others, we developed a hypothetical model to describe some of the mechanisms by which mGluRs may be involved in opioid tolerance and dependence $(84,85)$. The effect of a single, high dose injection of morphine is not entirely clear because some investigators (86) have found that glutamate release is increased in the striatum and nucleus accumbens, whereas others (87) have observed a decrease in the striatum and limbic forebrain. During chronic morphine administration, some investigators (88) observed a decrease in glutamate release; however, an increase in the glutamate to gamma-aminobutyric acid (GABA) ratio is found (87), suggesting that the glutamate concentration may be increased. Increased glutamate activity would overexcite not only NMDA receptors, but also mGluRs. During opioid withdrawal, an increase in glutamate release is generally observed $(86,87,89-91)$. First, we speculate that mGluRs, NMDA receptors and opioid receptors may be colocalized within the same cells. Brain distributions of mGluRs and opioid receptors are similar $(92,93)$, and it has been shown that NMDA receptors and opioid receptors are colocalized $(94,95)$. Increased activity of group I mGluRs would lead to an increase in PI hydrolysis, and thus activation of PKC and release of intracellular calcium from stores in the endoplasmic reticulum. Activated PKC would phosphorylate the G protein on the mu-opioid receptor (96-100), 


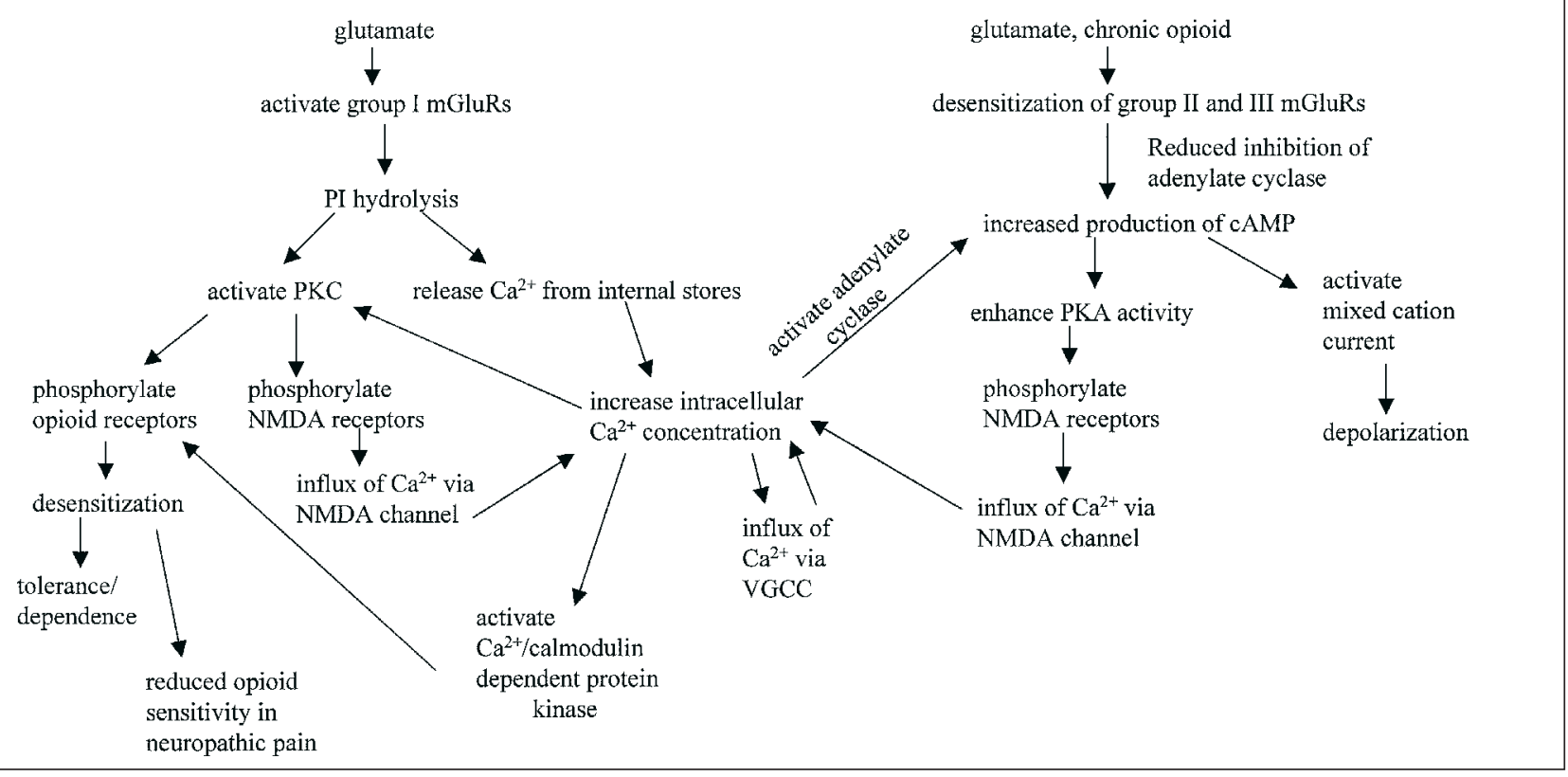

Figure 1) Flow chart depicting some of the mechanisms by which metabropic glutamate receptors (mGluRs) may be involved in opioid tolerance and dependence and neuropathic pain (especially with regard to decreased opioid sensitivity in neuropathic pain). PI Phosphatidylinositol; PKA Protein kinase A; PKC Protein kinase C; NMDA N-methyl-D-aspartate

inducing desensitization and, thus, tolerance. It would also phosphorylate the NMDA-associated ion channel (101-104), relieving the magnesium block and resulting in an enhancement of NMDA receptor activity, allowing a greater influx of calcium. Increased concentrations of intracellular calcium would promote influx of calcium via voltage-gated calcium channels (101-103), and further increasing the intracellular concentration of calcium. Increased concentrations of calcium may facilitate activation of calcium/calmodulindependent protein kinases, leading to further phosphorylation and desensitization of mu-opioid receptors $(81,105)$, as well as leading to the activation of adenylate cyclase and increased production of cAMP $(103,106)$. Increased concentrations of cAMP may enhance protein kinase A (PKA)-mediated phosphorylation of NMDA receptors $(32,107,108)$, elevate hyperpolarization-activated mixed cation current, causing depolarization $(88,109,110)$, and increase neuronal excitation. In regard to groups II and III mGluRs, we hypothesized that there was a heterologous desensitization of these receptors during chronic morphine treatment that is prevented by chronic administration of selective antagonists or overcome by a single injection of a selective agonist just before the precipitation of withdrawal. In support of this hypothesis, Noble and Cox (111) showed that repeated morphine administration induced heterologous desensitization of group III mGluRs in the caudate putamen, nucleus accumbens, thalamus and periaqueductal grey, as evidenced by a reduced ability of the group III agonist L-2-amino-4phosphobutyric acid to inhibit adenylate cyclase activity (Figure 1).

\section{GLUTAMATE AND NEUROPATHIC PAIN}

As discussed above, it has been suggested that opioid tolerance and dependence, and neuropathic pain may share similar mechanisms (1). Moreover, as discussed above, neuropathic pain is often unresponsive to opioid analgesics in both rats and humans (5-7,112-117 and unpublished data). Indeed, there is a great deal of evidence indicating that glutamate is involved in neuropathic pain as well as opioid tolerance and dependence. It has been shown that glutamate release is enhanced in the spinal cord of nerve-injured rats (118).

As in the study of opioid tolerance and dependence, most investigators have concentrated on the role of NMDA receptors in neuropathic pain. Many of these studies (119-135) have shown that NMDA antagonists, given either centrally or systemically, reduce hyperalgesia and allodynia associated with various models of nerve injury, as well as autotomy behaviour. However, it should be noted that this is not a universal observation. Some investigators have shown that, whereas administration of NMDA receptor antagonists reduces heat hyperalgesia, there is no appreciable effect on mechanical allodynia (136). It has also been shown that the effectiveness of opioid analgesics is restored in nerve-injured rats treated with NMDA antagonists $(112,113,115-117)$.

There is evidence suggesting that AMPA/kainate receptors are involved in neuropathic pain. It has been shown that administration of AMPA/kainate antagonists reduces hyperalgesia associated with constriction injury of the sciatic nerve, streptozotocin-induced diabetic neuropathy and dorsal rhizotomy in rats $(119,137,138)$, mechanical allodynia in spi- 
nal cord-injured rats $(139,140)$ and thermal sensitivity in spinalized rats (141). However, reduced muscle tone and sedation are often associated with the use of these antagonists (139).

Recent data from our laboratory indicate that mGluRs are also involved in both the development and maintenance of neuropathic pain. We showed that intrathecal administration of the relatively selective group I mGluR antagonist (S)-4CPG reduces the development of neuropathic pain (125). However, in addition to its antagonistic activity at group I mGluRs, (S)-4CPG has a secondary action whereby it is an agonist at group II mGluRs $(27,142,143)$. Therefore, the precise mechanism through which (S)-4CPG reduced neuropathic pain was not clear. We further explored the relative contribution of group I mGluRs by examining how pretreatment with antibodies selective to either mGluR1 or mGluR5 affected neuropathic pain. We showed that pretreatment with either anti-mGluR1 or anti-mGluR5 antibody significantly reduced cold hyperalgesia associated with a chronic constriction of the sciatic nerve (144). Therefore, we identified a clear role for group I mGluRs in neuropathic pain.

To characterize further the role of group I mGluRs in neuropathic pain, we used the novel technology of antisense oligonucleotides. We initially showed that intrathecal pretreatment with antisense oligonucleotides targeting either mGluR1 or mGluR5 reduced cold hyperalgesia, mechanical allodynia and heat hyperalgesia associated with nerve injury (145). The effect of knockdown of spinal mGluR1 was more robust than knockdown of spinal mGluR5; therefore, we continued our studies with the antisense targeting mGluR1 and examined the role of this receptor in more detail.

We showed that antisense oligonucleotide knockdown of spinal mGluR1 after neuropathic pain is already established significantly reversed cold hyperalgesia, mechanical allodynia and heat hyperalgesia (146 and unpublished data). These results suggest that mGluR1 is involved in the maintenance as well as the development of neuropathic pain.

As previously discussed, neuropathic rats and humans are relatively unresponsive to opioid analgesics. In further experiments, we showed that antisense oligonucleotide knockdown of spinal mGluR1 restored the efficacy of intrathecally injected morphine in nerve-injured rats (147 and unpublished data).

Activation of both NMDA receptors and group I mGluRs leads to the activation of PKC. Furthermore, activity at group I mGluRs positively modulates activity at NMDA receptors via a PKC-mediated mechanism (29-34). We and others $(1,78-82)$ have already shown that PKC is involved in opioid tolerance and dependence, and that PKC plays a pivotal role in neuropathic pain. When PKC is in the activated state, it is translocated to the membrane, and it has been shown that spinal PKC is translocated to the membrane in neuropathic rats (148). Moreover, inhibition of PKC in the spinal cord reduces morphine tolerance as well as decreases neuropathic pain $(80,149)$. By using transgenic animals in research studies, it has been shown that PKC knockout mice do not de- velop neuropathic pain (150). We verified that there is an increase in activated PKC in neuropathic rats, and we also showed that antisense oligonucleotide knockdown of spinal mGluR1 at the lumbar level results in a reduction of activated PKC in the lumbar spinal cord dorsal horn in neuropathic rats (146,151 and unpublished data).

Because of the effects of nerve injury on PKC activity, and the ability of group I mGluRs to modulate positively NMDA receptor activity via PKC-mediated mechanisms, we hypothesized that neuropathic rats would be hypersensitive to the excitatory effects of intrathecally injected NMDA and that antisense oligonucleotide knockdown of spinal mGluR1 would reverse this hypersensitivity. In experiments designed to test this hypothesis, we showed that nerve-injured rats are indeed hypersensitive to the excitatory effects of NMDA, as evidenced by increased time spent exhibiting nociceptive behaviours (151 and unpublished data). We also showed that antisense oligonucleotide knockdown of spinal mGluR1 reversed this NMDA hypersensitivity in neuropathic rats (151 and unpublished data).

Based on our results and those of others, we devised a hypothetical mechanistic model to explain the role of group I mGluRs in neuropathic pain, similar to our model to explain the role of mGluRs in opioid tolerance and dependence (84). We speculate that group I mGluRs, NMDA receptors and opioid receptors are colocalized within the same cells. Nerve injury stimulates an increased release of glutamate (118), therefore, increasing the activation of NMDA receptors and group I mGluRs. Activation of group I mGluRs (as well as NMDA receptors) ultimately leads to the activation of PKC. Activated PKC phosphorylates opioid receptors (96-100), leading to receptor desensitization and reduced efficacy of opioid agonist analgesics. In addition, PKC phosphorylates the NMDA-associated ion channel (101-104), increasing NMDA receptor activity, and leads to increased influx of calcium. The increased intracellular concentrations of calcium produce a positive feedback loop, increasing activity of protein kinases and enhancing the phosphorylation of opioid receptors and the NMDA ion channel. Antisense oligonucleotide knockdown of mGluR1 (and mGluR5) reduces the number of these receptors available for activation, reducing PI hydrolysis and protein kinase activation. Thus, the phosphorylation of opioid receptors and NMDA ion channels is attenuated, reducing desensitization of opioid receptors (with a resultant increase in opioid analgesic efficacy) and reducing activity of NMDA receptors (reducing cellular excitation and pain transmission) (Figure 1).

\section{DISCUSSION}

The roles of glutamate and glutamate receptors have been summarized - particularly those of mGluRs in opioid tolerance and dependence, and neuropathic pain, including opioid sensitivity associated with neuropathic pain. It has been shown that the inhibition of NMDA, AMPA and kainate receptors and mGluRs with antagonists, antibodies and antisense oligonucleotides attenuates opioid tolerance and dependence, and neuropathic pain, as well as restores opioid 
efficacy in nerve-injured animals. Selective agonists to group II mGluRs have also been shown to reduce opioid tolerance and dependence. These results suggest that glutamate receptors may be good targets for drug development for the clinical treatment of opioid tolerance and dependence, and neuropathic pain. Although NMDA antagonists have been

\section{REFERENCES}

1. Mao J, Price DD, Mayer DJ. Mechanisms of hyperalgesia and morphine tolerance: a current view of their possible interactions. Pain 1995;62:259-74.

2. Dyck PJ, Bushek W, Spring EM, et al. Vibratory and cooling detection thresholds compared with other tests in diagnosing and staging diabetic neuropathy. Diabetes Care 1987;10:432-40.

3. Portenoy RK. Cancer pain: pathophysiology and syndromes. Lancet 1992;339:1026-31.

4. McQuay HJ. Opioid use in chronic pain. Acta Anaesthesiol Scand 1997;41:175-83.

5. MacDonald N. Opiate-resistant pain: a therapeutic dilemma. Recent Results Cancer Res 1991;121:24-35.

6. McQuay HJ, Jadad AR, Carroll D, et al. Opioid sensitivity of chronic pain: a patient-controlled analgesia method. Anaesthesia 1992;47:757-67.

7. Cherny NI, Thaler HT, Friedlander-Klar H, et al. Opioid responsiveness of cancer pain syndromes caused by neuropathic or nociceptive mechanisms: combined analysis of controlled, single-dose studies. Neurology 1994;44:857-61.

8. Nakanishi S. Molecular diversity of glutamate receptors and implications for brain function. Science 1992;258:597-603.

9. MacDermott AB, Mayer ML, Westbrook GL, Smith SJ, Barker JL. NMDA-receptor activation increases cytoplasmic calcium concentration in cultured spinal cord neurones. Nature 1986;321:519-22.

10. Mayer ML, MacDermott AB, Westbrook GL, Smith SJ, Barker JL. Agonist- and voltage-gated calcium entry in cultured mouse spinal cord neurons under voltage clamp measured using Arsenazo III. J Neurosci 1987;7:3230-44.

11. Nowak L, Bregestovski P, Ascher P, Herbert A, Prochiantz A. Magnesium gates glutamate-activated channels in mouse central neurones. Nature 1984;307:462-5.

12. Mayer ML, Westbrook GL, Guthrie PB. Volatage-dependent block by $\mathrm{Mg}^{2+}$ of NMDA responses in spinal cord neurones. Nature 1984;309:261-3.

13. Cotman CW, Monaghan DT, Ganong AH. Excitatory amino acid neurotransmission: NMDA receptors and Hebb-type synaptic plasticity. Annu Rev Neurosci 1988;11:61-80.

14. Hollmann M, Heinemann S. Cloned glutamate receptors. Annu Rev Neurosci 1994;17:31-108.

15. Kemp JA, Leeson PD. The glycine site of the NMDA receptor - five years on. Trends Pharmacol Sci 1993;14:20-5.

16. Lodge D, Johnson KM. Noncompetitive excitatory amino acid receptor antagonists. In: D Lodge, GL Collingridge, eds. Trends in Pharmacological Science, Special Report: The Pharmacology of Excitatory Amino Acids. Cambridge: Elsevier, 1991:13-8.

17. Scott RH, Sutton KG, Dolphin AC. Interactions of polyamines with neuronal ion channels. Trends Neurosci 1993;16:153-60.

18. Sucher NJ, Awobuluyi M, Choi Y-B, Lipton SA. NMDA receptors: from genes to channels. Trends Pharmacol Sci 1996;17:348-55.

19. Morris R, Southam E, Gittins SR, de Vente J, Garthwaite J. The NO-cGMP pathway in neonatal rat dorsal horn. Eur J Neurosci 1994;6:876-9.

20. Murphy SN, Miller RJ. Regulation of $\mathrm{Ca}^{++}$influx into striatal neurons by kainic acid. J Pharmacol Exp Ther 1989;249:184-93.

21. Miller RJ. The revenge of the kainate receptor. Trends Neurosci 1991;14:477-9.

22. Sommer B, Seeburg PH. Glutamate receptor channels: novel properties and new clones. Trends Pharmacol Sci 1992;13:291-6. used clinically, their use is often associated with debilitating side effects such as memory, motor and cognitive impairments, and psychotomimetic effects (152-156). Either more selective NMDA antagonists, or perhaps other glutamate receptors, particularly mGluRs, are needed because they may be the best targets for future drug developments.

23. Cull-Candy SG, Ogden DC. Ion channels activated by L-glutamate and GABA in cultured cerebellar neurons of the rat. Proc R Soc Lond B Biol Sci 1985;224:367-73.

24. Kiskin NI, Krishtal OA, Tsyndrenko AYa. Excitatory amino acid receptors in hippocampal neurons: kainate fails to desensitize them. Neurosci Lett 1986;63:225-30.

25. Tang CM, Dichter M, Morad M. Quisqualate activates a rapidly inactivating high conductance ionic channel in hippocampal neurons. Science 1989;243:1474-7.

26. Trussell LO, Thio LL, Zorumski CF, Fischbach GD. Rapid desensitization of glutamate receptors in vertebrate central neurons. Proc Natl Acad Sci USA 1988;85:4562-6.

27. Hayashi Y, Sekiyama N, Nakanishi S, et al. Analysis of agonist and antagonist activities of phenylglycine derivatives for different cloned metabotropic glutamate receptor subtypes. J Neurosci 1994;14:3370-7.

28. Conn PJ, Pin JP. Pharmacology and function of metabotropic glutamate receptors. Annu Rev Pharmacol Toxicol 1997;37:205-37.

29. Bleakman D, Rusin KI, Chard PS, Glaum SR, Miller RJ. Metabotropic glutamate receptors potentiate ionotropic glutamate responses in the rat dorsal horn. Mol Pharmacol 1992;42:192-6.

30. Chen L, Huang LY. Protein kinase C reduces Mg2+ block of NMDA-receptor channels as a mechanism of modulation. Nature 1992;356:521-3.

31. Kelso SR, Nelson TE, Leonard JP. Protein kinase C-mediated enhancement of NMDA currents by metabotropic glutamate receptors in Xenopus oocytes. J Physiol 1992;449:705-18.

32. Harvey J, Collingridge GL. Signal transduction pathways involved in the acute potentiation of NMDA responses by $1 \mathrm{~S}, 3 \mathrm{R}-\mathrm{ACPD}$ in rat hippocampal slices. Br J Pharmacol 1993;109:1085-90.

33. Kitamura Y, Miyazaki A, Yamanaka Y, Nomura Y. Stimulatory effects of protein kinase $\mathrm{C}$ and calmodulin kinase II on $N$-methyl-D-aspartate receptor/channels in the postsynaptic density of rat brain. J Neurochem 1993;61:100-9.

34. Raymond LA, Tingley WG, Blackstone CD, Roche KW, Huganir RL. Glutamate receptor modulation by protein phosphorylation. J Physiol Paris 1994;88:181-92.

35. Martin G, Nie Z, Siggins GR. Metabotropic glutamate receptors regulate $N$-methyl-D-aspartate-mediated synaptic transmission in nucleus accumbens. J Neurophysiol 1997;78:3028-38.

36. Jhamandas KH, Marsala M, Ibuki T, Yaksh TL. Spinal amino acid release and precipitated withdrawal in rats chronically infused with spinal morphine. J Neurosci 1996;15:2758-66.

37. Aghajanian GK, Kogan JH, Moghaddam B. Opiate withdrawal increases glutamate and aspartate efflux in the locus coeruleus: an in vivo microdialysis study. Brain Res 1994;636:126-30.

38. Tokuyama S, Wakabayashi H, Ho IK. Direct evidence for a role of glutamate in the expression of the opioid withdrawal syndrome. Eur J Pharmacol 1996;295:123-9.

39. Lizasoain I, Leza JC, Cuellar B, Moro MA, Lorenzo P. Inhibition of morphine withdrawal by lamotrigine: involvement of nitric oxide. Eur J Pharmacol 1996;299:41-5.

40. Koyuncuoglu H, Gungor M, Sagduyu H, Eroglu L. The antagonistic effects of aspartic acid on some effects of morphine on rats. Eur J Pharmacol 1974;27:148-50.

41. Koyuncuoglu H, Sagduyu H, Güngör M, Eroglu L, Genc E. Antagonizing effect of aspartic acid on the development of physical dependence on and tolerance to morphine in the rat. Arzneimittelforschung 1977;27:1676-9.

42. Koyuncuoglu H, Güngör M, Sagduyu H, Aricioglu F. Suppression by 
ketamine and dextromethorphan of precipitated abstinence syndrome in rats. Pharmacol Biochem Behav 1990;35:829-32.

43. Trujillo KA, Akil H. Inhibition of morphine tolerance and dependence by the NMDA receptor antagonist MK-801. Science 1991;251:85-7.

44. Trujillo KA, Akil H. Inhibition of opiate tolerance by non-competitive $N$-methyl-D-aspartate receptor antagonists. Brain Res 1994:633:178-88.

45. Mao J, Price DD, Mayer DJ. Mechanisms of hyperalgesia and morphine tolerance: a current view of their possible interactions. Pain 1995;62:259-74

46. Marek P, Ben-Eliyahu S, Gold M, Liebeskind JC. Excitatory amino acid antagonists (kynurenic acid and MK-801) attenuate the development of morphine tolerance in rats. Brain Res 1991;547:77-81.

47. Marek P, Ben-Eliyahu S, Vaccarino AL, Liebeskind JC. Delayed application of MK-801 attenuates development of morphine tolerance in rats. Brain Res 1991;558:163-5.

48. Gonzalez P, Cabello P, Germany A, Norris B, Contreras E. Decrease of tolerance to, and physical dependence on morphine by, glutamate receptor antagonists. Eur J Pharmacol 1997;332:257-62.

49. Makimura M, Sugimoto H, Shinomiya K, Kabasawa Y, Fukuda H. Inhibitory effect of the NMDA receptor antagonist, dizocilpine (MK-801), on the development of morphine dependence. J Toxicol Sci 1996;21:135-41.

50. Herman BH, Vocci F, Bridge P. The effects of NMDA receptor antagonists and nitric oxide synthase inhibitors on opioid tolerance and withdrawal. Medication development issues for opiate addiction. Neuropsychopharmacology 1995;13:269-93.

51. Bhargava HN. Non-competitive antagonism of $N$-methyl-D-aspartate receptor inhibits tolerance to the analgesic action of U-50,488H, a kappa-opiate receptor agonist in the rat. Gen Pharmacol 1995;26:1055-60.

52. Elliott K, Hynansky A, Inturrisi CE. Dextromethorphan attenuates and reverses analgesic tolerance to morphine. Pain 1994;59:361-8.

53. Mao J, Price DD, Lu J, Mayer DJ. Antinociceptive tolerance to the mu-opioid agonist DAMGO is dose-dependently reduced by MK-801 in rats. Neurosci Lett 1998;250:193-6.

54. McCarthy RJ, Kroin JS, Tuman KJ, Penn RD, Ivankovich AD. Antinociceptive potentiation and attenuation of tolerance by intrathecal co-infusion of magnesium sulfate and morphine in rats. Anesth Analg 1998;86:830-6.

55. Manning BH, Mao J, Frenk H, Price DD, Mayer DJ. Continuous co-admininstration of dextromethorphan or MK-801 with morphine: attenuation of morphine dependence and naloxone-reversible attenuation of morphine tolerance. Pain 1996;67:79-88.

56. Lutfy K, Shen KZ, Woodward RM, Weber E. Inhibition of morphine tolerance by NMDA receptor antagonists in the formalin test. Brain Res 1996;731:171-81.

57. Popik P, Skolnick P. The NMDA antagonist memantine blocks the expression and maintenance of morphine dependence. Pharmacol Biochem Behav 1996;53:791-7.

58. Zhao GM, Bhargava HN. Effect of antagonism of the NMDA receptor on tolerance to [D-Pen2,D-Pen5]enkephalin, a delta 1-opioid receptor agonist. Peptides 1996;17:233-6.

59. Fundytus ME, Coderre TJ. Effect of activity at metabotropic, as well as ionotropic (NMDA), glutamate receptors on morphine dependence. Br J Pharmacol 1994;113:1215-20.

60. Allen RM, Dykstra LA. The competitive NMDA receptor antagonist LY235959 modulates the progression of morphine tolerance in rats. Psychopharmacology (Berl) 1999;142:209-14.

61. Kolesnikov Y, Pasternak GW. Topical opioids in mice: analgesia and reversal of tolerance by a topical $N$-methyl-D-aspartate antagonist. J Pharmacol Exp Ther 1999;290:247-52.

62. Wong CS, Cherng CH, Luk HN, Ho ST, Tung CS. Effects of NMDA receptor antagonists on inhibition of morphine tolerance in rats: binding at mu-opioid receptors. Eur J Pharmacol 1996;297:27-33.

63. Lutfy K, Shen KZ, Kwon IS, et al. Blockade of morphine tolerance by ACEA-1328, a novel NMDA receptor/glycine site antagonist. Eur J Pharmacol 1995;273:187-9.
64. Popik P, Mamczarz J, Fraczek M, Widla N, Hasselink M, Danysz W. Inhibition of reinforcing effects of morphine and naloxone precipitated opioid withdrawal by novel glycine site and uncompetitive NMDA receptor antagonists. Neuropharmacology 1998;37:1033-42.

65. Kosten TA, DeCaprio JL, Rosen MI. The severity of naloxone precipitated withdrawal is attenuated by felbamate, a possible glycine antagonist. Neuropsychopharmacology 1995;13:323-33.

66. Zhu H, Ho IK. NMDA-R1 antisense oligonucleotide attenuates withdrawal signs from morphine. Eur J Pharmacol 1998;352:151-6.

67. Bilsky EJ, Inturrisi CE, Sadee W, Hruby VJ, Porreca F. Competitive and non-competitive NMDA antagonists block the development of antinociceptive tolerance to morphine, but not to selective mu or delta opioid agonists in mice. Pain 1996;68:229-37.

68. Elliott K, Kest B, Man A, Kao B, Inturrisi CE. $N$-methyl-D-aspartate (NMDA) receptors, mu and kappa opioid tolerance, and perspectives on new analgesic drug development. Neuropsychopharmacology 1995; 13:347-56

69. Pasternak GW, Kolesnikov YA, Babey AM. Perspectives on the $N$-methyl-D-aspartate/nitric oxide cascade and opioid tolerance. Neuropsychopharmacology 1995;13:309-13.

70. Bell JA, Beglan CL. Co-treatment with MK-801 potentiates naloxone-precipitated morphine withdrawal in the isolated spinal cord of the neonatal rat. Eur J Pharmacol 1995;294:297-301.

71. Taylor JR, Punch LJ, Elsworth JD. A comparison of the effects of clonidine and CNQX infusion into the locus coeruleus and the amygdala on naloxone-precipitated opiate withdrawal in the rat. Psychopharmacology (Berl) 1998;138:133-42.

72. Rasmussen K, Kendrick WT, Kogan JH, Aghajanian GK. A selective AMPA antagonist, LY293558, suppresses morphine withdrawalinduced activation of locus coeruleus neurons and behavioral signs of morphine withdrawal. Neuropsychopharmacology 1996;15:497-505.

73. McLemore GL, Kest B, Inturrisi CE. The effects of LY293558, an AMPA receptor antagonist, on acute and chronic morphine dependence. Brain Res 1997;778:120-6.

74. Kest B, McLemore G, Kao B, Inturrisi CE. The competitive alpha-amino-3-hydroxy-5-methylisoxazole-4-propionate receptor antagonist LY293558 attenuates and reverses analgesic tolerance to morphine but not to delta or kappa opioids. J Pharmacol Exp Ther 1997;283:1249-55.

75. Fundytus ME, Ritchie J, Coderre TJ. Attenuation of morphine withdrawal symptoms by subtype selective metabotropic glutamate receptor antagonists. Br J Pharmacol 1997;120:1015-20.

76. Vandergriff J, Rasmussen $\mathrm{K}$. The selective $\mathrm{mGlu} 2 / 3$ receptor agonist LY354740 attenuates morphine-withdrawal-induced activation of locus coeruleus neurons and behavioral signs of morphine withdrawal. Neuropharmacol 1999;38:217-22.

77. Fundytus ME, Coderre TJ. Attenuation of precipitated morphine withdrawal symptoms by acute i.c.v. administration of a group II mGluR agonist. Br J Pharmacol 1997;121:511-4.

78. Fundytus ME, Coderre TJ. Chronic inhibition of intracellular Ca2+ release or protein kinase $\mathrm{C}$ activation significantly reduces the development of morphine dependence. Eur J Pharmacol 1996;300:173-81.

79. Mao J, Price DD, Mayer DJ. Thermal hyperalgesia in association with the development of morphine tolerance in rats: roles of excitatory amino acid receptors and protein kinase C. J Neurosci 1994;14:2301-12.

80. Mayer DJ, Mao J, Price DD. The development of morphine tolerance and dependence is associated with translocaton of protein kinase $\mathrm{C}$. Pain 1995;61:365-74.

81. Maldonado R, Valverde O, Garbay C, Roques BP. Protein kinases in the locus coeruleus and periaqueductal gray matter are involved in the expression of opiate withdrawal. Naunyn Schmiedebergs Arch Pharmacol 1995;352:565-75.

82. Narita M, Feng Y, Makimura M, Hoskins B, Ho IK. A protein kinase inhibitor, H-7, inhibits the development of tolerance to opioid antinociception. Eur J Pharmacol 1994;271:543-5. 
83. Mao J, Price DD, Phillips LL, Lu J, Mayer DJ. Increases in protein kinase $\mathrm{C}$ gamma immunoreactivity in the spinal cord of rats associated with tolerance to the analgesic effects of morphine. Brain Res 1995;677:257-67.84.

84. Fundytus ME, Coderre TJ. Opioid tolerance and dependence: A new model highlighting the role of metabotropic glutamate receptors. Pain Forum 1999;8:3-13.

85. Fundytus ME, Coderre TJ. mGluRs and opioid dependence: A further examination of the mechanisms. Pain Forum 1999;8:59-63.

86. Huang NK, Tseng CJ, Wong CS, Tung CS. Effects of acute and chronic morphine on DOPAC and glutamate at subcortical DA terminals in awake rats. Pharmacol Biochem Behav 1997;56:363-71.

87. Desole MS, Esposito G, Fresu L, et al. Effects of morphine treatment and withdrawal on striatal and limbic monoaminergic activity and ascorbin acid oxidation in the rat. Brain Res 1996;723:154-61.

88. Ingram SL, Williams JT. Modulation of the hyperpolarizationactivated current (Ih) by cyclic nucleotides in guinea-pig primary afferent neurons. J Physiol (Lond) 1996;492:97-106.

89. Hoshi K, Ma T, Oh S, Ho IK. Increased release of excitatory amino acids in rat locus coeruleus in kappa-opioid agonist dependent rats precipitated by nor-binaltorphimine. Brain Res 1997;753:63-8.

90. Jhamandas KH, Marsala M, Ibuki T, Yaksh TL. Spinal amino acid release and precipitated withdrawal in rats chronically infused with spinal morphine. J Neurosci 1996;16:2758-66.

91. Tokuyama S, Ho IK. Inhibitory effects of diltiazem, and L-type Ca2+ channel blocker, on naloxone-increased glutamate levels in the locus coeruleus of opioid-dependent rats. Brain Res 1996;722:212-6.

92. Mansour A, Fox CA, Akil H, Watson SJ. Opioid-receptor mRNA expression in the rat CNS: anatomical and functional implications. Trends Neurosci 1995;18:22-9.

93. Masu M, Nakajima Y, Moriyoshi K, Ishii T, Akazawa C, Nakanishi S. Molecular characterization of NMDA and metabotropic glutamate receptors. Ann NY Acad Sci 1993;707:153-64.

94. Commons KG, van Bockstaele EJ, Pfaff DW. Frequent colocalization of mu opioid and NMDA-type glutamate receptors at postsynaptic sites in periaqueductal gray neurons. J Comp Neurol 1999;408:549-59.

95. Gracy KN, Svingos AL, Pickel VM. Dual ultrastructural localization of mu-opioid receptors and NMDA-type glutamate receptors in the shell of the rat nucleus accumbens. J Neurosci 1997;17:4839-48.

96. Childers SR. Opioid receptor-coupled second messenger systems. Life Sci 1991;48:1991-2003.

97. Fan GH, Zhao J, Wu YL, et al. $N$-methyl-D-aspartate attenuates opioid receptor-mediated $\mathrm{G}$ protein activation and this process involves protein kinase C. Mol Pharmacol 1998;53:684-90.

98. Kramer HK, Simon EJ. Role of protein kinase C (PKC) in agonist-induced mu-opioid receptor down-regulation: II. Activation and involvement of the alpha, epsilon and zeta isoforms of PKC. J Neurochem 1999;72:594-604.

99. Narita M, Mizoguchi H, Kampine JP, Tseng LF. Role of protein kinase $\mathrm{C}$ in desensitization of spinal delta-opioid-mediated antinociception in the mouse. Br J Pharmacol 1996;118:1829-35.

100. Wang L, Medina VM, Rivera M, Gintzler AR. Relevance of phosphorylation state to opioid responsiveness in opiate naive and tolerant/dependent tissue. Brain Res 1996;723:61-9.

101. Lambert DG. Signal transduction: G proteins and second messengers. Br J Anaesth 1993;71:86-95.

102. Lambert DG, Wojcikiewicz RJH, Safrany ST, Whitham EM, Nahorski SR. Muscarinic receptors, phosphoinositide metabolism and intracellular calcium in neuronal cells. Prog Neuro Psychopharmacol Biol Psychiatry 1992;16:253-70.

103. Smart D, Lambert DG. The stimulatory effects of opioids and their possible role in the development of tolerance. Trends Pharmacol Sci 1996; 17:264-9.

104. Swope SL, Moss SI, Raymond LA, Huganir RL. Regulation of ligand-gated ion channels by protein phosphorylation. Adv Second Messenger Phosphoprotein Res 1999;33:49-78.

105. Mestek A, Hurley JH, Bye LS, et al. The human mu opioid receptor: modulation of functional desensitization by calcium/calmodulin- dependent protein kinase and protein kinase C. J Neurosci 1995;15:2396-406.

106. Hirst RA, Lambert DG. Adenylyl cyclase in SH-SY5Y human neuroblastoma cells is regulated by intra- and extra-cellular calcium. Biochem Pharmacol 1995;49:1633-40.

107. Cerne R, Rusin KI, Randic M. Enhancement of the $\mathrm{N}$-methyl-D-aspartate response in spinal dorsal horn neurons by cAMP-dependent protein kinase. Neurosci Lett 1993;161:124-8.

108. Leonard AS, Hell JW. Cyclic AMP-dependent protein kinase and protein kinase $\mathrm{C}$ phosphorylate $\mathrm{N}$-methyl-D-aspartate receptors at different sites. J Biol Chem 1997;272:12107-15.

109. Kingston PA, Zufall F, Barnstable CJ. Rat hippocampal neurons express genes for both rod retinal and olfactory cyclic nucleotide-gated channels: novel targets for cAMP/cGMP function. Proc Natl Acad Sci USA 1996;93:10440-5.

110. Pedarzani P, Storm JF. Protein kinase A-independent modulation of ion channels in the brain by cyclic AMP. Proc Natl Acad Sci USA 1995;92:11716-20.

111. Noble F, Cox BM. Differential desensitization of mu- and delta- opioid receptors in selected neural pathways following chronic morphine treatment. Br J Pharmacol 1996;117:161-9.

112. Ossipov MH, Lopez Y, Nichols ML, Bian D, Porreca F. Inhibition by spinal morphine of the tail-flick response is attenuated in rats with nerve ligation injury. Neurosci Lett 1995;199:83-6.

113. Ossipov MH, Lopez Y, Nichols ML, Bian D, Porreca F. The loss of antinociceptive efficacy of spinal morphine in rats with nerve ligation injury is prevented by reducing spinal afferent drive. Neurosci Lett 1995; 199:87-90.

114. Mao J, Price DD, Mayer DJ. Experimental mononeuropathy reduces the antinociceptive effects of morphine: implications for common intracellular mechanisms involved in morphine tolerance and neuropathic pain. Pain 1995;61:353-64.

115. Christensen D, Idanpaan-Heikkila JJ, Guilbaud G, Kayser V. The antinociceptive effect of combined systemic administration of morphine and the glycine/NMDA receptor antagonist, (+)-HA966 in a rat model of peripheral neuropathy. Br J Pharmacol 1998;125:1641-50.

116. Kauppila T, Xu XJ, Yu W, Wiesenfeld-Hallin Z. Dextromethorphan potentiates the effect of morphine in rats with peripheral neuropathy. Neuroreport 1998;9:1071-4

117. Nichols ML, Lopez Y, Ossipov MH, Bian D, Porreca F. Enhancement of the anitallodynic and antinociceptive efficacy of spinal morphine by antisera to dynorphin A (1-13) or MK-801 in a nerve-ligation model of peripheral neuropathy. Pain 1997;69:317-22.

118. Al-Ghoul WM, Volsi GL, Weinberg RJ, Rustioni A. Glutamate immunocytochemistry in the dorsal horn after injury or stimulation of the sciatic nerve of rats. Brain Res Bull 1993;30:453-9.

119. Calcutt NA, Chaplan SR. Spinal pharmacology of tactile allodynia in diabetic rats. Br J Pharmacol 1997;122:1478-82.

120. Carlton SM, Hargett GL. Treatment with the NMDA antagonist memantine attenuates nociceptive responses to mechanical stimulation in neuropathic rats. Neurosci Lett 1995;198:115-8.

121. Malcangio M, Tomlinson DR. A pharmacological analysis of mechanical hyperalgesia in streptozotocin/diabetic rats. Pain 1998;76:151-7.

122. Mao J, Price DD, Hayes RL, Lu J, Mayer DJ, Frenk H. Intrathecal treatment with dextrorphan or ketamine potently reduces pain-related behaviors in a rat model of peripheral mononeuropathy. Brain Res 1993;605:164-8

123. Mao J, Price DD, Mayer DJ, Lu J, Hayes RL. Intrathecal MK-801 and local nerve anesthesia synergistically reduce nociceptive behaviors in rats with experimental peripheral mononeuropathy. Brain Res 1992;576:254-62.

124. Mao J, Price DD, Hayes RL, Lu J, Mayer DJ. Differential roles of NMDA and non-NMDA receptor activation in induction and maintenance of thermal hyperalgesia in rats with painful peripheral mononeuropathy. Brain Res 1992;598:271-8.

125. Fisher K, Fundytus ME, Cahill CM, Coderre TJ. Intrathecal administration of the mGluR compound, (S)-4CPG, attenuates 
hyperalgesia and allodynia associated with sciatic nerve constriction injury in rats. Pain 1998;77:59-66.

126. Kim YI, Na HS, Yoon YW, Han HC, Ko KH, Hong SK. NMDA receptors are important for both mechanical and thermal allodynia from peripheral nerve injury in rats. NeuroReport 1997;8:2149-53.

127. Tal M, Bennett GJ. Dextrorphan relieves neuropathic heat-evoked hyperalgesia in the rat. Neurosci Lett 1993;151:107-10.

128. Davar G, Hama A, Deykin A, Vos B, Maciewicz R. MK-801 blocks the development of thermal hyperalgesia in a rat model of experimental painful neuropathy. Brain Res 1991;553:327-30.

129. Boyce S, Wyatt A, Webb JK, et al. Selective NMDA NR2B antagonists induce antinociception without motor dysfunction: correlation with restricted localization of NR2B subunit in dorsal horn. Neuropharmacology 1999;38:611-23.

130. Burton AW, Lee DH, Saab C, Chung JM. Preemptive intrathecal ketamine injection produces a long-lasting decrease in neuropathic pain behaviors in a rat model. Reg Anesth Pain Med 1999;24:208-13.

131. Munglani R, Hudspith MJ, Fleming B, et al. Effect of pre-emptive NMDA antagonist treatment on long-term Fos expression and hyperalgesia in a model of chronic neuropathic pain. Brain Res 1999;822:210-9.

132. Qian J, Brown SD, Carlton SM. Systemic ketamine attenuates nociceptive behaviors in a rat model of peripheral neuropathy. Brain Res 1996;715:51-62.

133. Wong CS, Cherng CH, Tung CS. Intrathecal administration of excitatory amino acid receptor antagonists or nitric oxide synthase inhibitor reduced autotomy behavior in rats. Anesth Analg 1998;87:605-8.

134. Tseng SH. Suppression of autotomy by $N$-methyl-D-aspartate receptor antagonist (MK-801) in the rat. Neurosci Lett 1998;240:17-20.

135. Banos JE, Verdu E, Buti M, Navarro X. Effects of dizocilpine on autotomy behavior after nerve section in mice. Brain Res 1994;636:107-10.

136. Tal M, Bennett GJ. Neuropathic pain sensations are differentially sensitive to dextrorphan. Neuroreport 1994;5:1438-40.

137. Mao J, Price DD, Hayes RL, Lu J, Mayer DJ. Differential roles of NMDA and non-NMDA receptor activation in induction and maintenance of thermal hyperalgesia in rats with painful peripheral mononeuropathy. Brain Res 1992;598:271-8.

138. Carlton SM, Hargett GL, Coggeshall RE. Plasticity in alpha-amino3-hydroxy-5-methyl-4-isooxazolepropionic acid receptor subunits in the rat dorsal horn following deafferentation. Neurosci Lett 1998;242:21-4.

139. Hao JX, Xu XJ. Treatment of a chronic allodynia-like response in spinally injured rats: effects of systemically administered excitatory amino acid receptor antagonists. Pain 1996;66:279-85.

140. Xu XJ, Hao JX, Seiger A, Wiesenfeld-Hallin Z. Systemic excitatory amino acid receptor antagonists of the alpha-amino-3-hydroxy-5methyl-4-isoxazolepropionic acid (AMPA) receptor and of the $N$-methyl-D-aspartate (NMDA) receptor relieve mechanical hypersensitivity after transient spinal cord ischemia in rats. J Pharmacol Exp Ther 1993;267:140-4.
141. Advokat C, Rutherford D. Selective antinociceptive effect of excitatory amino acid antagonists in intact and acute spinal rats. Pharmacol Biochem Behav 1995;51:855-60.

142. Eaton SA, Jane DE, Jones PL, et al. Competitive antagonism at metabotropic glutamate receptors by (S)-4-carboxyphenylglycine and (RS)-alpha-methyl-4-carboxyphenylglycine. Eur J Pharmacol 1993;244:195-7.

143. Watkins JC, Collingridge GL. Phenylglycine derivatives as antagonists of metabotropic glutamate receptors. Trends Pharmacol Sci 1994;15:333-42.

144. Fundytus ME, Fisher K, Dray A, Henry JL, Coderre TJ. In vivo antinociceptive activity of anti-rat mGluR1 and anti-rat mGluR5 antibodies in rats. Neuroreport 1998;9:731-5.

145. Fundytus ME, Fisher K, Dray A, Henry JL, Coderre TJ. Antisense oligonucleotides targeting group I mGluRs attenuate nerve constriction-induced hyperalgesia and allodynia. Soc Neurosci Abstr 1997;23:1013.

146. Fundytus ME, Henry JL, Dray A, Coderre TJ. Antisense knockdown of mGluR $_{1}$ reverses hyperalgesia/allodynia associated with an established neuropathic injury in rats. Proceedings of the $\mathrm{Ix}^{\text {th }}$ World Congress on Pain, Vienna, Austria, August 22-27, 1999. (In press)

147. Fundytus ME, Dray A, Henry JL, Coderre TJ. An antisense oligonucleotide targeting $\mathrm{mGluR}_{1}$ restores opioid sensitivity in neuropathic rats. Int Narc Res Conf Abstr 1998;p 42.

148. Mao J, Price DD, Phillips LL, Lu J, Mayer DJ. Increases in protein kinase $\mathrm{C}$ gamma immunoreactivity in the spinal cord dorsal horn of rats with painful mononeuropathy. Neurosci Lett 1995;198:75-8.

149. Mao J, Price DD, Hayes RL, Lu J, Mayer DJ. Intrathecal GM1 ganglioside and local nerve anesthesia reduce nociceptive behaviors in rats with experimental peripheral mononeuropathy. Brain Res 1992;584:28-53.

150. Malmberg AB, Chen CC, Tonegawa S, Basbaum AI. Preserved acute pain and reduced neuropathic pain in mice lacking PKC gamma. Science 1997;278:279-83.

151. Fundytus ME, Yashpal K, Dray A, Coderre TJ, Henry JL. Antisense oligonucleotide knockdown of mGluR $_{1}$ reverses enhanced NMDA sensitivity in neuropathic rats. Soc Neurosci Abstr 1999;25:449.

152. Birch PJ. Clinical relevance of receptor pharmacology in the nociceptive pathway. Pain Rev 1995;2:13-27.

153. Schugens MM, Egerter R, Daum I, Schepelmann K, Klockgether T, Loschmann PA. The NMDA antagonist memantine impairs classical eyeblink conditioning in humans. Neurosci Lett 1997;224:57-60.

154. Muir KW, Grosset DG, Lees KR. Effects of prolonged infusions of the NMDA antagonist aptiganel hydrochloride (CNS 1102) in normal volunteers. Clin Neuropharmacol 1997;20:311-21.

155. Murman DL, Giordani B, Mellow AM, et al. Cognitive, behavioral, and motor effects of the NMDA antagonist ketamine in Huntington's disease. Neurology 1997;49:153-61.

156. Max MB, Byas-Smith MG, Gracely RH, Bennett GJ. Intravenous infusion of the NMDA antagonist, ketamine, in chronic posttraumatic pain with allodynia: a double-blind comparison to alfentanil and placebo. Clin Neuropharmacol 1995;18:360-8. 


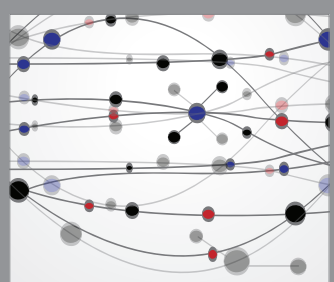

The Scientific World Journal
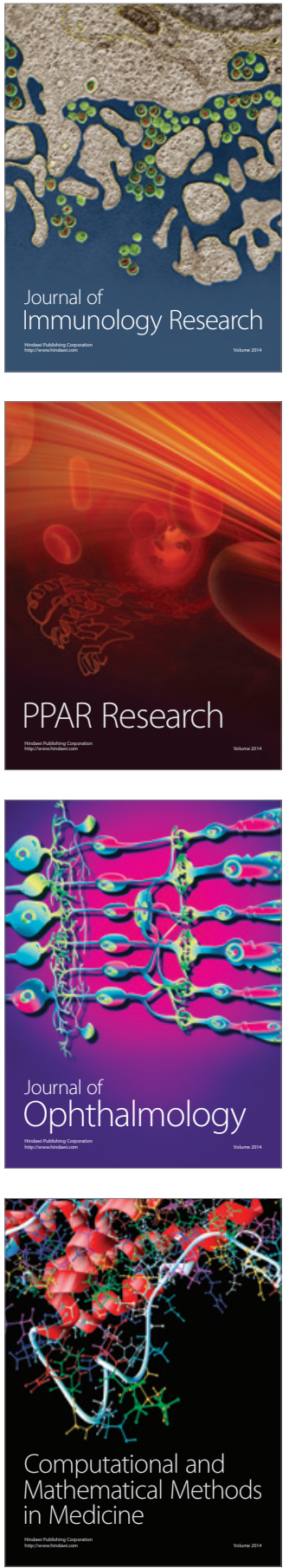

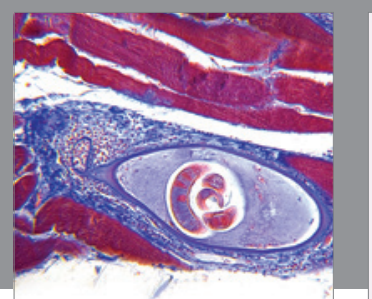

Gastroenterology Research and Practice

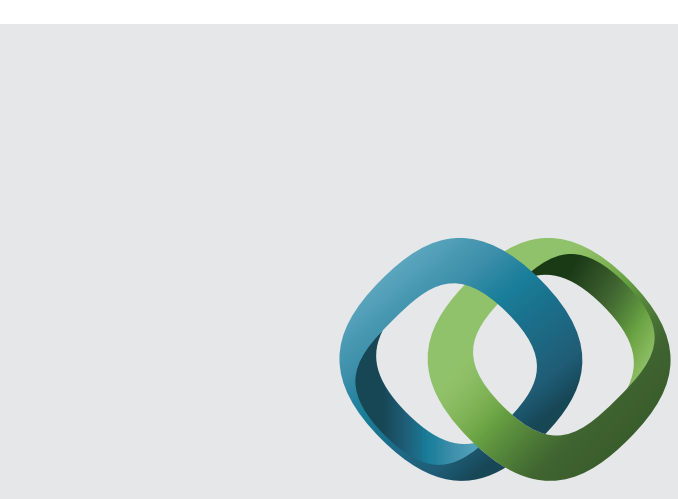

\section{Hindawi}

Submit your manuscripts at

http://www.hindawi.com
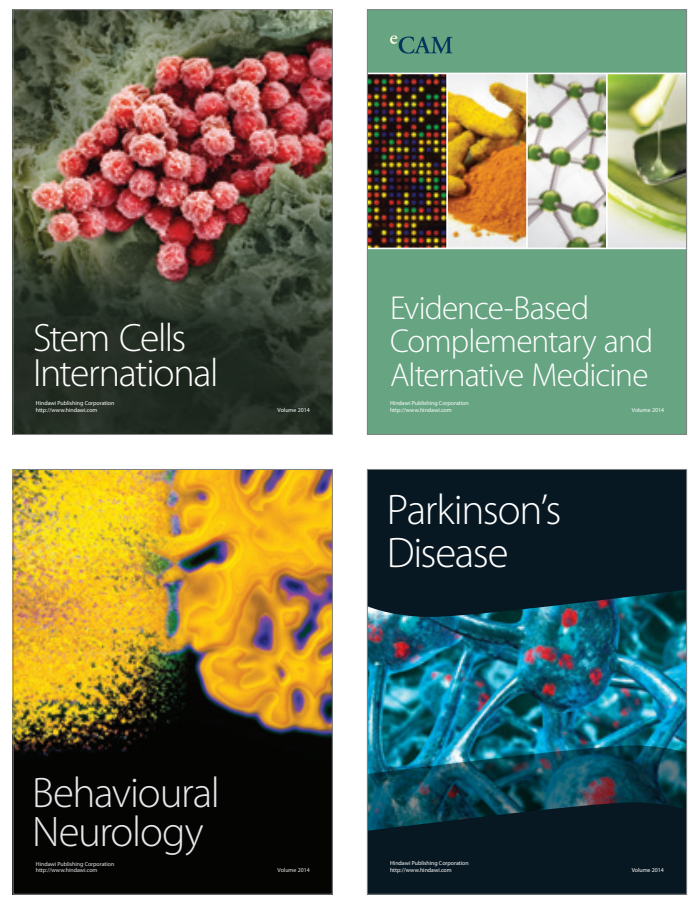
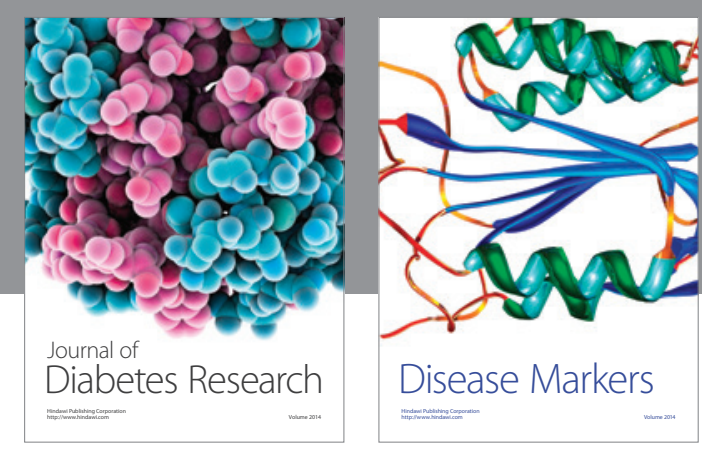

Disease Markers
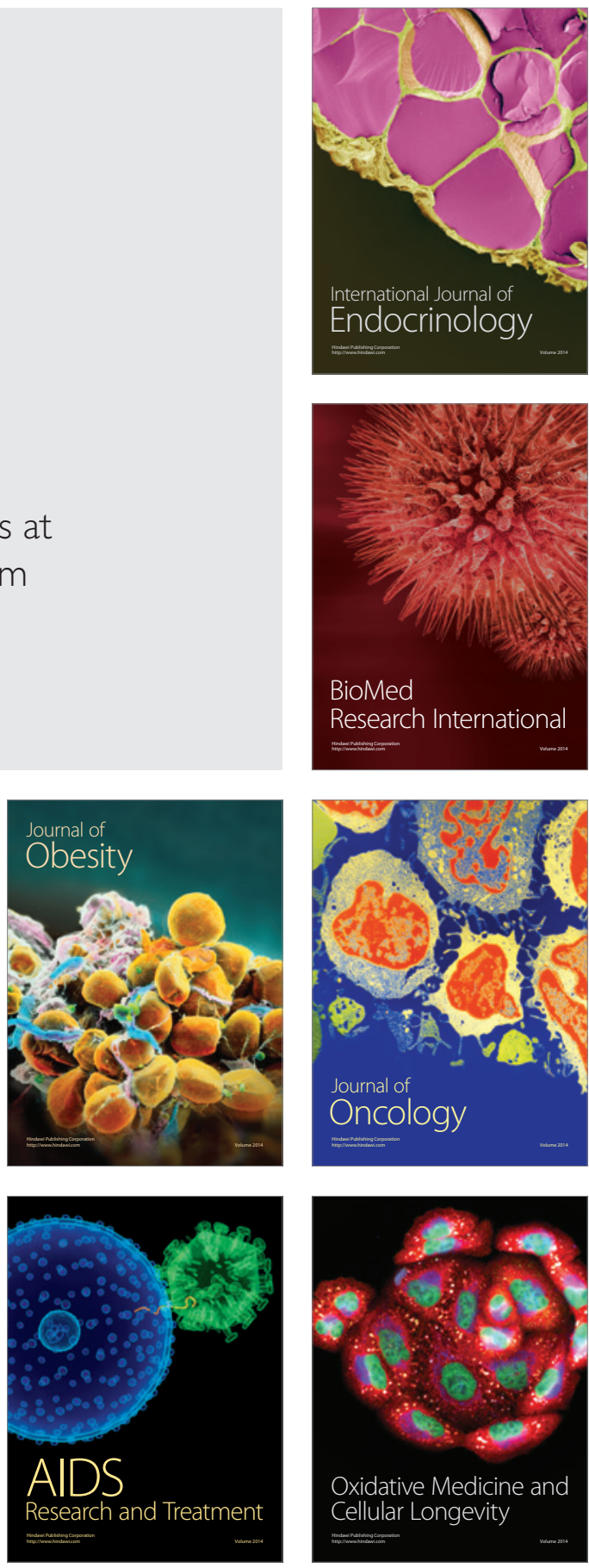